\title{
PENILAIAN KINERJA KEUANGAN PT. BANK MUAMALAT INDONESIA, TBK DENGAN METODE ECONOMIC VALUE ADDED
}

\author{
Fathia Ahya Nur Iman, Arry Widodo \\ Fakultas Komunikasi dan Bisnis Universitas Telkom \\ E-mail: fathia.ahya@yahoo.com; \\ arry.widodo@gmail.com
}

\begin{abstract}
The purpose of this study to determine the financial performance with the use of the EVA method to the assessment of the performance of PT Bank Mualamat Indonesia Tbk in the period 2010 - 2014. The research method used is quantitative descriptive method using Economic Value Added (EVA), which is an analytical method for evaluating the performance a company to take measurements of the profits (value) economically produced by the company during the period (period of time) specific. The results show the value of Bank Muamalat EVA is negative, meaning that Bank Muamalat in the year 20102014 can not create value-added enterprise or net operating profit after taxes (NOPAT) produced by the company is not able to finance or cover all capital costs or expenses incurred. In 2014 the value of EVA Bank Muamalat increasing, although still negative.
\end{abstract}

Keywords : Economic Value Added, Financial Performance, Islamic Banking,

\begin{abstract}
Abstrak
Tujuan penelitian ini untuk mengetahui kinerja keuangan dengan penggunaaan metode EVA terhadap penilaian kinerja PT Bank Mualamat Indonesia Tbk pada periode 2010 - 2014. Metode penelitian yang digunakan adalah metode deskriptif kuantitatif dengan menggunakan Economic Value Added (EVA) yang merupakan suatu metode analisis untuk penilaian terhadap kinerja sebuah perusahaan dengan melakukan pengukuran terhadap laba (nilai) ekonomis yang dihasilkan perusahaan pada periode (jangka waktu) tertentu. Hasil penelitian menunjukkan nilai EVA Bank Muamalat negatif, artinya Bank Muamalat pada tahun 2010-2014 tidak dapat menciptakan nilai tambah perusahaan atau laba usaha bersih setelah pajak (NOPAT) yang dihasilkan oleh perusahaan tidak mampu membiayai atau menutupi semua beban atau biaya modal yang dikeluarkan. Pada tahun 2014 nilai EVA Bank Muamalat mengalami peningkatan walaupun tetap bernilai negatif.
\end{abstract}

Kata kunci : Bank Syariah, Economic Value Added, Kinerja Keuangan 
Ekonomika-Bisnis,Vol. 7 No. 1 Bulan Januari Tahun 2016 Hal 15-22

Pertumbuhan aset pada bank syariah dengan kondisi ekonomi dan keuangan global secara umum mengalami perlambatan pada tahun 2013 dibandingkan periode sebelumnya. Namun, kinerja maupun perkembangan perbankan dan keuangan syariah nasional secara umum masih memiliki pertumbuhan yang cukup positif. Dapat dilihat dari pertumbuhan aset perbankan syariah mencapai $24,2 \%$ year on year (yoy). Potensi pengembangan perbankan dan keuangan syariah kedepan masih memiliki kesempatan untuk berkembang, walaupun masih tetap dihadapkan dengan berbagai tantangan seperti permodalan, sumber daya manusia, business process, inovasi dan akad atau kontrak produk serta edukasi maupun pemaha-man masyarakat yang berkesinam-bungan (mysharing.co/2015).

Pertumbuhan asset perbankan syariah pada 2010 mengalami kenaikkan sebesar $47 \%$ yakni sebesar Rp. 100,26 triliun dibandingkan tahun sebelumnya pada tahun 2011 aset perbankan syariah naik sebesar $49 \%$ yakni sebesar Rp. 149 triliun (www.republika.co.id) dan pada 2012 mengalami peningkatan $34 \%$ yakni sebesar Rp. 199,7 triliun (www.bi.go.id/2015). Meskipun lam-bat, total aset bank syariah dari $2013 \mathrm{ke}$ 2014 tetap mengalami pertumbuhan. Namun pertumbuhannya tidak sebesar pertumbuhan tahun-tahun sebelumnya yang bisa mencapai $30 \%$. Pertumbuhan aset dari 2013 ke 2014 sekitar 12 $\%$, tetap ada kenaikan, tetapi tidak sebesar tahun sebelumnya, sebelumnya bisa $30 \%$ (economy.okezone.com/2015).

Bank Muamalat merupakan pelopor bank syariah di Indonesia dan merupakan bank syariah pertama yang terdaftar di Bursa Efek Indonesia (BEI) sehingga Bank Muamalat memiliki data keuangan dan data tahunan dengan sistem keuangan syariah murni yang terdapat di BEI, hal ini berbeda jika dibandingkan dengan bank umum syariah lain yang sudah terdaftar di BEI, yang mempunyai laporan keuangan dan laporan tahunan masih terkosolidasi dengan bank konven-sional atau baru terdaftar di tahun 2015.

Berdasarkan data di antaranews (2016) perbankan syariah di Indonesia khususnya untuk Bank Muamalat masih mendapatkan kepercayaan dari masyarakat, meskipun pertumbuhan ekonomi pada tahun 2014 mengalami penurunan. Bank Muamalat mendapat penghargaan sebagai Bank Syariah Terbaik di Indonesia untuk yang ke-7 kalinya dari Islamic Finance News (IFN) yang berlangsung di Malaysia, dengan predikat sebagai Best Islamic Retail Bank dan Best Islamic Bank in Indonesia.

Kondisi laba bersih Bank Muamalat yang diperoleh pada tahun 2010 sampai 2012 mengalami kenaikkan sebesar $83 \%$, namun pada tahun 2013 laba bersih mengalami penurunan sebesar $49,9 \%$, mengalami penurunan kembali pada tahun 2014 yakni sebesar $65 \%$ dibandingkan 2013, dan total penurunan yang cukup signifikan pada PT.Bank Muamalat,Tbk 2012-2014 yakni sebesar $82 \%$. Penurunan laba terjadi karena dampak turunnya pertumbuhan ekonomi di Indonesia pada tahun 2014. Kondisi pertumbuhan ekuitas Bank Muamalat dari tahun 2010 menuju 2013 mengalami kenaik-kan sebesar $145 \%$ namun mengalami penurunan pada tahun 2013 menuju 2014 sebesar 6,2\% (www.republika.co.id/2016). 
Penilaian Kinerja Keuangan ...( Fathia Ahya Nur Iman, Arry Widodo)

Data yang telah disajikan
merupakan sebagian data Laporan
keuangan yang merupakan ringkasan
dari kegiatan ekonomi yang dijalankan
suatu perusahaan dapat mencerminkan
kondisi perusahaan. Menurut Brigham
$\& \quad$ Houston (2013:84) Laporan
keuangan adalah beberapa lembar
kertas dengan angka-angka yang
tertulis di atasnya, tetapi juga untuk
memikirkan aset-aset nyata yang berada
di balik angka tersebut. Kondisi laporan
keuangan dapat memper-lihatkan
kinerja keuangan suatu perusahaan.
Kinerja keuangan adalah suatu analisis
yang dilakukan untuk melihat sejauh
mana suatu entitas telah melaksanakan
dengan menggunakan aturan-aturan
pelaksanaan keuangan secara baik dan
benar (Fahmi, 2012:2).
Penilaian kinerja terdapat bebe-
rapa cara diantaranya dengan analisis
rasio. Namun, menurut Brigham \&
Houston (2013:84) analisis rasio
memiliki keterbatasan yakni: (1)

Kebanyakan perusahaan besar mengoperasikan beberapa divisi dalam industri yang berlainan, dan bagi perusahaan seperti akan sulit untuk mengembangkan rata-rata industri yang berarti. Oleh karena itu, analisis rasio lebih bermanfaat bagi perusahaan kecil yang memiliki fokus lebih sempit dibandingkan perusahaan besar yang multidivisional. (2) Inflasi telah mendistorsikan neraca banyak perusahaannilai tercatat sering kali sangat jauh berbeda dengan nilai yang sebenarnya. Inflasi mempengaruhi baik beban penyusutan maupun harga perolehan persediaan, maka laba juga ikut terpengaruh. Jadi analisis rasio untuk satu perusahaan dari waktu ke waktu atau analysis komparatif beberapa perusahaan dari waktu yang berbeda-

beda, harus diterjemahkan dengan pertimbangan yang masak.

Brigham \& Houston menyatakan Economic Value Added (EVA) berbeda dari ukuran akuntansi tradi-sional atas laba karena EVA secara eksplisit tidak hanya memper-timbagkan biaya hutang, tetapi juga biaya ekuitas (Brigham \& Houston, 2013:165) dimana jika nilai EVA positif, maka laba operasi setelah pajak melebihi biaya modal yang dibutuhkan untuk menghasilkan laba tersebut, dan tindakan manajemen menambah nilai saham. Brigham \& Houston (2013:112).

Berdasarkan uraian diatas, maka tujuan penelitian ini adalah untuk mengetahui kinerja keuangan Bank Muamalat Indonesia dan perkembangan keuangan PT.Bank Muamalat Indonesia,Tbk pada periode 2010-2014 dengan menggunakan metode EVA.

\section{Metode Penelitian}

Data yang akan digunakan dalam perhitungan atau analisis penelitian ini diperoleh dengan menggunakan data data laporan keuangan dari PT.Bank Muamalat Indonesia periode 20102014 terdapat di BEI berupa laporan laba rugi (income statement) dan neraca (balance sheet) tahun 2010-2014, Serta mendapatkan data kepustakaan dari berbagai sumber seperti buku, jurnal, internet, dan informasi lainnya yang dianggap relevan dengan topik penelitian.

Penelitian ini dilakukan oleh peneliti yang ingin mendeskripsikan kinerja keuangan dan juga ingin melihat besarnya nilai tambah pada Bank Muamalat. Analisis kinerja keuangan Bank Muamalat digunakan metode EVA. Tahapan analisis dalam penelitian ini dengan menggunakan 
Ekonomika-Bisnis, Vol. 7 No. 1 Bulan Januari Tahun 2016 Hal 15-22

tahapan (Brigham \& Houston, 2013:111): Pertama, Economic Value Added (EVA)

$\mathrm{EVA}=\operatorname{EBIT}(1-\mathrm{T})-\left[\begin{array}{l}X \\ \times \\ Y\end{array}\right]$

$\mathrm{EVA}=\mathrm{NOPAT}-\mathrm{COC}$

Dimana: $X=$ Total modal operasi yang berasal dari investor; dan $\mathrm{Y}=$ presetase biaya modal setelah pajak.

Kedua, Nilai NOPAT didapatkan dengan menggunakan Rumus NOPAT (Brigham \& Houston, 2013:111):

NOPAT $=$ EBIT $(1-$ Tarif Pajak $)(3)$

Ketiga, Cost of Capital (COC)

(Martono \& Harjito, 2012:201):

$$
\begin{aligned}
\text { COC }= & \text { Cost of Debt After Tax }+ \\
& \text { Saham Preferen }+ \\
& \text { Biaya Ekuitas }
\end{aligned}
$$

Keempat, Menghitung nilai WACC Brigham \& Houston, 2014:7): $W A C C=\llbracket(D x r d)(1-t a x)+$

$$
(E \times r e) \rrbracket
$$

Kelima, Invested Capital perusahaan (Manurung, 2011:98)

Invested Capital $=$ Total Hutang dan Ekuitas - Pinjaman Jangka Pendek (6)

Keenam, Menghitung Struktur Modal (Ari, 2010:41):

$$
\begin{array}{r}
k_{e}=\underset{D A C C}{ }+\left(\text { WACC }-k_{d}\right) \times \\
\ldots / E
\end{array}
$$

\section{Hasil Penelitian dan Pembahasan}

Langkah pertama pada penelitian ini adalah menghitung nilai NOPAT. Hasil NOPAT dapat dilihat pada tabel 1 .

Hasil perhitungan NOPAT Bank Muamalat Sejak 2010 ke 2012 mengalami kenaikan dari Rp.173,Miliyar naik sebesar Rp.391,- Miliyar, hal tersebut dikarenakan nilai laba usaha setelah pajak meningkat sebesar $125 \%$. Sedangkan nilai NOPAT terkecil pada tahun 2014 yaitu sebesar
Rp. 72,- Milliyar hal tersebut dikarenakan laba usaha pada

Tabel 1. NOPAT PT Bank Muamalat Indonesia Tahun 2010-2014 (dalam ribuan rupiah)

\begin{tabular}{ll}
\hline Tahun & NOPAT \\
\hline 2010 & Rp173.307.530 \\
2011 & Rp278.752.700 \\
2012 & Rp391.380.991 \\
2013 & Rp179.512.950 \\
2014 & Rp72.539.851 \\
\hline
\end{tabular}

Sumber: data olahan (2016).

tahun 2014 dengan melihat pertumbuhan NOPAT pada 2012 menuju 2014 mengalami penurunan sebesar $81 \%$. Namun yang terjadi peningkatan pendapatan usaha sejak tahun 2010 sampai 2014 sebesar $224 \%$, dan kenaikkan beban usaha tahun 2010 sampai 2014 sebesar $132 \%$.

Tahap kedua yaitu Perhitungan COC. Biaya modal atau cost of capital merupakan konsep penting untuk perusahaan, dengan adanya biaya modal dimaksudkan untuk dapat menentukan biaya riil yang harus ditanggung perusahaan untuk memperoleh dana dari suatu sumber.

Tabel 2. COC PT Bank Muamalat Indonesia Tahun 2010-2014 (dalam ribuan rupiah)

\begin{tabular}{lc}
\hline Tahun & COC (dalam Ribuan Rupiah) \\
\hline 2010 & Rp. 2.459.364.703 \\
2011 & Rp 3.544.802.725 \\
2012 & Rp 7.273.959.985 \\
2013 & Rp 8.673.635.514 \\
2014 & Rp 7.924.006.325 \\
\hline Sumber: data diolah (2016).
\end{tabular}

Berdasarkan hasil analisis menunjukkan adanya perbedaan dimana ketika COC dihitung menggunakan persentase (\%) maka pada tahun 2010 menuju 2011 mengalami kenaikkan yakni sebesar $18,18 \%$ namun sejak tahun 2012 mengalami penurunan 
Penilaian Kinerja Keuangan ...( Fathia Ahya Nur Iman, Arry Widodo)

sampai pada tahun 2014 sebesar 20,68\%. Namun nilai COC pada perhitungan dengan menggunakan nominal mata uang rupiah mengalami kenaikkan pada tahun 2010 sampai 2013 yakni sebesar $252 \%$ dan mengalami penurunan pada tahun 2014 sebesar $8,8 \%$. Hal ini disebabkan oleh biaya ekuitas yakni berupa laba ditahan pada tahun 2014 dianggap nol karena tidak tercantum pada laporan keuangan pada tahun 2014 sebab pembagian dividen dilakukan secara rutin pada pertengahan tahun yakni pertengahan tahun 2015 sehingga baru akan tercantum pada laporan keuangan tahun 2015.

Tahap ketiga, Perhitungan WACC. Nilai WACC Bank Muamalat periode 2010-2014 mengalami penurunan yang cukup signifikan yakni sebesar $47,65 \%$ hal tersebut disebabkan hasil dari perhitungan biaya ekuitas (rs). Pada tahun 2014 perolehan laba ditahan belum diketahui sehingga mempengaruhi nilai WACC (lihat tabel $3)$.

Tabel 3. Nilai WACC PT Bank Muamalat Indonesia Tbk Tahun 2010-2014 (dalam bentuk \%)

\begin{tabular}{cc}
\hline Tahun & WACC \\
\hline 2010 & $55,63 \%$ \\
2011 & $44,46 \%$ \\
2012 & $26,88 \%$ \\
2013 & $22,97 \%$ \\
2014 & $8,22 \%$ \\
\hline
\end{tabular}

Sumber: data diolah (2016).

Pada tahun 2011 sampai 2014 biaya modal atau COC mengalami penurunan dan pada biaya operasional tahun 2014 mengalami kenaikkan dibandingkan 2013 yakni sebesar 125\% atau sebesar Rp. 6 trilliun sehingga dapat mempengaruhi nilai perolehan WACC karena WACC merupakan biaya modal rata-rata setelah pajak dari masing-masing sumber modal yang digunakan oleh perusahaan untuk meganalisa keputusan penganggaran modal terhadap biaya operasional.

Tahap berikutnya yaitu Perhitungan Invested Capital. Berdasarkan hasil perhitungan Invested Capital Bank Muamalat pada tahun 2010 selalu mengalami kenaikkan sampai 2014 sebesar $182 \%$. Hal ini disebabkan oleh total hutang dan ekuitas pada tahun 2010 hingga 2014 mengalami peningkatan sebesar $178 \%$ dan hutang jangka pendek mengalami fluktuatif setiap tahunnya yakni tahun 2010 menuju 2011 mengalami penurunan sebesar 7,5\%, tahun 2011 menuju 2012 mengalami peningkatan yang cukup signifikan yakni sebesar $70 \%$, tahun 2012 menuju 2013 mengalami penurunan sebesar $65 \%$ dan mengalami peningkatan sebesar 100\% (lihat tabel 4).

Tabel 4. Nilai Invested Capital PT Bank Muamalat Indonesia Tbk Tahun 2010-2014 (dalam ribuan rupiah)

\begin{tabular}{cl}
\hline Tahun & \multicolumn{1}{c}{ Invested Capital } \\
\hline 2010 & Rp. 4.728 .212 .951 \\
2011 & Rp. 6.242 .423 .137 \\
2012 & Rp. 10.406 .490 .244 \\
2013 & Rp. 13.139.250.401 \\
2014 & Rp. 13.371.526.454 \\
\hline \multicolumn{2}{l}{ Sumber: data diolah (2016) }
\end{tabular}

Sumber: data diolah (2016)

Tahap berikutnya yaitu Perhitungan Struktur Modal. Berdasarkan hasil perhitungan struktur modal Bank Muamalat pada tahun 2010 dapat diketahui bahwa Bank Muamalat selalu mengalami penurunan secara signifikan sampai 2014 sebesar 164,21\%. Hal ini disebabkan oleh nilai WACC yang mengalami penurunan setiap tahunnya yakni pada periode 2010- 
2014, rd (biaya hutang) mengalami peningkatan pada tahun 2010-2013 meskipun pada tahun 2014 mengalami penurunan namun dalam jumlah kecil yakni hanya sebesar $4,18 \%$, dan hutang dan Equity yang meningkat. Namun yang paling berpengaruh pada struktur modal yakni dengan melihat nilai WACC.

Tabel 5. Nilai Struktur Modal PT Bank Muamalat Indonesia Tbk Tahun 2010-2014 (dalam \%)

\begin{tabular}{lc}
\hline Tahun & Struktur Modal \\
\hline 2010 & $175,32 \%$ \\
2011 & $155,62 \%$ \\
2012 & $138,28 \%$ \\
2013 & $103,76 \%$ \\
2014 & $11,11 \%$ \\
\hline
\end{tabular}

Sumber: Data Diolah (2016).

Tahap yang terakhir yaitu Perhitungan EVA. Hasil perhitungan EVA dapat dilihat pada tabel 6.

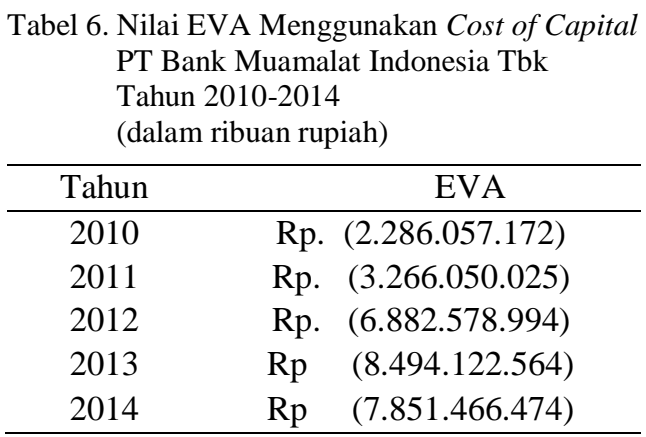

Sumber: data diolah (2016).

Berdasarkan rumus yang digunakan untuk menghitung nilai EVA Pada PT Bank Muamalat Indonesia menghasilkan nilai EVA lebih kecil dari nol atau bernilai negatif pada posisi ini Bank Muamalat pada tahun 2010-2014 tidak dapat menciptakan nilai tambah dan tidak terjadinya pembagian dividen dari Bank Muamalat kepada investor secara langsung melainkan dibagikan dalam bentuk dividen saham yang dimasu-kkan dalam tambahan modal yang disetor setiap tahunnya.

Hal ini mempengaruhi nilai EVA menjadi negatif. Namun pada posisi tahun 2010-2012 Bank Muamalat tetap menciptakan nilai yang positif dengan melihat laba yang dihasilkan sehingga pada penambahan saham yang didapat dari pembagian dividen yang ditambah secara langsung dengan saham ikut bertambah.

\section{Penutup}

Berdasarkan dari hasil analisis dan perhitungan Economic Value Added (EVA) pada PT Bank Muamalat Indonesia Tbk periode 2010-2014 menunjukkan nilai EVA negatif yang artinya perusahaan tidak mampu menciptakan nilai tambah, atau laba yang dihasilkan tidak mampu memenuhi harapan bagi pemegang saham perusahaan (investor) pada periode tersebut. perkembangan kinerja keuangan dengan menggunakan metode EVA PT Bank Muamalat Indonesia Tbk periode 2010-2014 mengalami penurunan hal ini disebabkan pada 2010-2013 nilai EVA negatif yang dihasilkan semakin menurun meskipun pada tahun 2014 meningkat sebesar $7,6 \%$ kearah positif.

\section{DAFTAR PUSTAKA}

Antonio, Muhammad Syafi'i. 2014. Bank Syariah Dari Teori ke Praktik, 22 ed. Jakarta: Gema Insani.

Ari, S. D. 2010. Manajemen Keuangan Lanjut. Yogyakarta: Graha Ilmu

Brigham, F. Eugene., \& Houston, F., Joel. 2013. Dasar-dasar 
Penilaian Kinerja Keuangan ...( Fathia Ahya Nur Iman, Arry Widodo)
Manajemen Keuangan (11 ed., Vol. Buku ke 1). Jakarta: Salemba Empat.
Brigham, F. Eugene., \& Houston, F., Joel. 2014. Dasar-dasar Manajemen Keuangan (11 ed., Vol. Buku ke 2). Jakarta: Salemba Empat.

Fahmi, I. 2012. Analisis Laporan Keuangan. Bandung: AlfaBeta.

Kasmir. 2011. Bank dan Lembaga Keuangan Lainnya (Revisi ed.). Jakarta: Rajawali Pers.

Manurung, P. D. 2011. Valuasi Wajar Perusahaan. Jakarta: Adler Manurung Press.

Martono \& Harjito, Agus. 2012. Manajemen Keuangan (2 ed.). Yogyakarta: Ekonosia.

Pitakasari, Ajeng Ritzki. 2011. Alhamdulillah... Perbankan Syariah Nasional Tumbuh 47 Persen.

http://www.republika.co.id/berita /bisnissyariah/berita/11/02/11/163706alhamdulillah-perbankansyariah-nasional-tumbuh-47persen. (20 Maret 2016).

Rudianto. 2013. Akuntansi Manajemen: Informasi untuk Pengambilan Keputusan Strategis. Jakarta: Erlangga.

Sugianto, Danang. 2015. Bank Muamalat Pangkas Target Laba 2015. economy.okezone.com/2015/ (6
November 2015 pukul 11:12 PM).

Sugiyono. 2014. Metode Penelitian Kuantitatif, Kualitatif, dan $R \& D$ (21 ed.). Bandung: Alfabeta. . 2013. Statistika Untuk Penelitian (23 ed.). Bandung: Alfabeta.

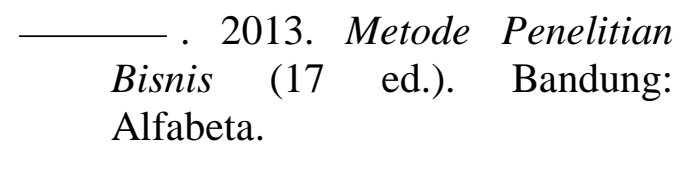

Suharso, Yudi. 2014. Industri Perbankan Syariah Indonesia Tumbuh Positif di 2014. http://mysharing.co/industriperba nkansyariahindonesiatumbuhposi tifdi2014. Diakses pada 6 November 2015.

Syafputri, Ella. 2015. IFN: Muamalat bank syariah terbaik. http://www.antaranews.com/berit a/484569/ifnmuamalatbanksyaria hterbaik. Diakses pada 9 Januari 2016.

Young, S. David \& O'Byrne, Stephen F. 2001. EVA and Value Based Management A Practical Guide To Implementation. US Amerika: McGraw-Hill. 
Ekonomika-Bisnis,Vol. 7 No. 1 Bulan Januari Tahun 2016 Hal 15-22 